\title{
The Florentine Scolari Family at the Court of Sigismund of Luxemburg in Buda
}

\author{
Katalin Prajda \\ European University Institute
}

\begin{abstract}
By the beginning of the fifteenth century, European commercial centers had already been filled with trading colonies founded by Florentine merchants. A few of them settled down for life in their host country, developing economic and social ties with local families. During Sigismund of Luxemburg's reign (r. 1387-1437) as King of Hungary only a handful of these merchants achieved political positions. Undoubtedly the most fortunate among these Florentine citizens was Filippo di Stefano Scolari, known as Pippo Spano (c. 1369-1426), who was granted the significant honor of becoming a member of a small inner circle in the royal court. This article argues that the special status attained by Florentines in Hungarian politics and economy during the first three decades of the fifteenth century can be attributed largely to Pippo Spano's influence. As cultural mediators, Pippo Spano and his family helped to facilitate relations between their native Florence and their adopted home. This case study focuses on the Scolari family's migration to the Hungarian Kingdom in order to explore on a small scale the possible push-pull factors of migration flow and its impact on the relationship between the Florentine Republic and the Hungarian Kingdom.
\end{abstract}

\section{Keywords}

Hungary, Florence, kinship network, mediation, migration, Pippo Spano

\section{The Florentine Presence in the Hungarian Kingdom in the Late Fourteenth Century}

The modern states of Hungary, Romania, and Slovakia, all of which are situated in part on the territory of medieval Hungarian Kingdom, include several national and ethnic minorities, some of which can trace their roots back to the Middle Ages. Due to the continuous migration of foreign ethnic groups from Western and Eastern Europe, the medieval Hungarian Kingdom maintained a multiethnic political character from its foundation. As a result of the Hungarian kings' dynastic relations with other 
European royal families and because of the many privileges that the new immigrants enjoyed, the greater part of the population of royal towns, which were free from any seigniorial obligation, was composed of citizens of immigrant origins. This character is also found in many other towns of the Hungarian realm that were subject to seigniorial obligations, but which boasted economic attractions, such as mining and market towns. Medieval documents note the constant migration of Germans to these towns. There were also Muslims and Jewish frequently mentioned, similar to the presence of Walloons and Italians at the most important centers of commerce in the Kingdom. Members of these ethnic groups, together with smaller indigenous groups, took the lead in local as well as of the international trade throughout the Hungarian Kingdom during Sigismund of Luxemburg's reign (1387-1437). ${ }^{1}$

The neglect by historians of the history of Florentine or even Italian migration into the Hungarian Kingdom before Sigismund's reign makes it difficult to identify precisely the beginning of the republic's relationship with the Hungarian Kingdom. ${ }^{2}$ For the period preceding this study, the reign of Louis I (r. 1342-1382), there are a few sources documenting the Florentine presence in the Hungarian Kingdom, some of which have lain unexamined until now. These documents illustrate that the early migration of Florentines into the Hungarian Kingdom fell into two patterns. ${ }^{3}$ The

1 Pál Engel, The Realm of St Stephen. A history of medieval Hungary. 895-1526. (New York, 2001), 244-266; Katalin Szende, "Integration through Language: The Multilingual Character of Late Medieval Hungarian Towns," in eds. Derek Keene, Balázs Nagy, Katalin Szende, Segregation, Integration, Assimilation: Religious and Ethnic Groups in the Medieval Towns of Central and Eastern Europe (Farnham-Burlington, 2009), 205-234.

2 Krisztina Arany, "Firenzei-magyar kereskedelmi kapcsolatok a 15. Században," in eds. András Kubinyi, József, Laszlovszky, Péter Szabó, Gazdaság és gazdálkodás a középkori Magyarországon: gazdaságtörténet, anyagi kultúra, régészet, (Budapest, 2008), 277-293; Martin Štefánik, "Kupfer aus dem ungarischen Königreich im Spiegel der venezianischen Senatsprotokolle im 14. Jahrhundert," in eds. Rudolf Tasser, Ekkehard Westermann, Der Tiroler Bergbau und die Depression der europäischen Montanwirtschaft im 14. und 15. Jahrhundert. Akten der internationalen bergbaugeschichtlichen Tagung (Innstbruck, 2004), 210-226.

${ }^{3}$ A version of this paper was delivered in Chicago, at the annual conference of the Renaissance Society of America, 3-5 April 2008. I am especially grateful to Jennifer Mara DeSilva for reviewing the manuscript and to Catherine Fletcher, Gábor Szatlóczki, and the two anonymous readers for their valuable comments. Over the years, this research has benefited from the support of the Department of History and Civilization at the European University Institute, Florence, Italy. 
first of these patterns was typical of agents of merchant companies and cannot properly be called migratory. Rather, these migrants are best thought of as commuters who moved between the two states. Included in this group were also a small number of politicians who travelled to the kingdom mainly as ambassadors of the republic, and who followed a similar back-and forth pattern. Alongside this temporary diffusion of Florentines into the Hungarian economy, there were also a small number of true immigrants to the kingdom who met a royal demand for labor in various capacities. ${ }^{4}$ The shortage of skilled men can be seen mainly in the administrative sector of the medieval labor market. Despite of having some of the largest deposits of gold, silver, copper and salt, Hungarian kings rarely had enough talented officials to run the mines and mints. This was probably due to the composition of indigenous Hungarian society, and essentially to the absence of a solid group of well-trained citizens. As a result, Hungarian kings often hired officers of Western European origins, among which was a significant number of Italians.

Many temporary migrants served the royal court and the nobility, along with the kingdom's largest towns, as importers of Florentine luxury goods. Export goods including gold, silver, and copper, naturally also captured the attention of a few Florentine international companies. One of these early exporters, Vieri di Cambio de' Medici (1323-1395), began transporting Hungarian copper to Venice around 1387.5 Agents of such trading companies were continuously present in the region throughout the late fourteenth and fifteenth centuries. As the story of Bonaccorso di Neri Pitti (c. 1343-c. 1427) illustrates, in the early 1370s it was common for international merchants, such as Matteo di Scelto Tinghi, to take abroad young shop assistants who were required to have training at a foreign branch of the company. ${ }^{6}$ As Bonaccorso's example suggests, this training allowed

\footnotetext{
${ }^{4}$ In this study permanent migration as applies to a person who was present in the Hungarian Kingdom in at least two different years. Meanwhile, the term "temporary migration" applies to those cases in which merchants followed a back and forth pattern between the two lands without holding any offices in the Hungarian Kingdom or having any social connections with local families.

${ }^{5}$ Archivio di Stato di Firenze (hereafter ASF), Signori, Missive I. Cancelleria 21. 129v.

${ }^{6}$ Bonaccorso Pitti, "Ricordi" in ed. Vittore Branca, Mercanti scrittori: Ricordi nella Firenze tra Medioevo e Rinascimento (Milano, 1986), 366-367. It is worth mentioning that in 1427 Bonaccorso's household included his sons and grandchildren, among them the nine-year-old Bonaccorso di Luca ASF Catasto 66. 154v. Bonaccorso married Matteo Scolari's daughter, Francesca, in the early 1440s, ASF Notarile Antecosimiano 15130.43r.
} 
young merchants to establish economic and political relations with other experienced Florentine merchants, as well as with Hungarian noblemen.

The merchant character of the Florentine republic revealed itself in the Signorias frequent commissioning of citizens traveling to Buda on commercial enterprises as diplomatic agents, carrying massages or attending the royal court as ambassadors. The dual role of merchant-ambassador reveals the close relationship between trade and politics as perceived by elite members of the Florentine republic. The merchant Andrea di messer Lorenzo Buondelmonte served as Florentine ambassador several times. ${ }^{7}$ In 1396, the Dieci di Balìa sent him with Grazia Castellani to Sigismund's court in order to strengthen relations with the Hungarian crown. ${ }^{8}$ While at the royal court, the ambassadors did not miss the occasion to make connections with the most influential Hungarian barons. The count palatine, the archbishop of Esztergom, and the bishop of Pécs were all members of the royal court who maintained connections with Florentine politicians in the late fourteenth century. ${ }^{9}$ The Signoria's choice of Andrea Buondelmonte as ambassador seems natural based on indirect sources that shed light on his long-lasting relations with the Hungarian Kingdom. Four of his six sons, Lorenzo, Niccolò, Simone, and Giovanni, became eminent figures in the later Florentine diaspora. In the first decades of the fifteenth century, all of Andrea's sons engaged in long-distance trade between Florence and Buda, cooperating constantly with the Scolari family as reliable men who were also distant paternal relatives. ${ }^{10}$ Thanks to their services to and good relations with Pippo Spano, one of the brothers, Giovanni Buondelmonte, was nominated first to the abbacy of the Benedictine monastery at Pécsvárad and in 1424 to the archbishopric of Kalocsa. ${ }^{11}$

\footnotetext{
${ }^{7}$ He acted as ambassador several times in the 1390s and in the first decade of the fifteenth century, ASF Signori, Legazioni e commissarie 1. 113v; ASF Dieci di Balìa, Legazioni e commissarie 3. 192r; 356r.

${ }^{8}$ ASF Dieci di Balìa, Relazioni di ambasciatori 20v-21r; Dieci di Balìa, Legazioni e commissarie 2. 17rbis.

${ }^{9}$ Letters of recommendation addressed by the Signoria to Hungarian dignities: ASF Signori Missive I. Cancelleria 21. 40v (1388, to the bishop of Pécs); Signori Missive I. Cancelleria 24. 154v (to the archbishop of Esztergom); Signori Missive I. Cancelleria 21. $89 \mathrm{v} ; 40 \mathrm{v}$ (1390, to the Count Palatine).

${ }_{10}$ ASF Corporazioni Religiose Soppresi (hereafter: Corp.Rel.Sopp.) 78.326.292v; 260v. Simone was also nominated by Pippo Spano as one of the executors of Andrea Scolari's last will, ASF Carte Strozziane IV. 635.

${ }^{11}$ According to the letter of Giovanni di Niccolò Falcucci, one of the Scolari's fellowmerchants, Giovanni's nomination was due to Pippo Spano's political power: “ò avuto let-
} 
The success of the Buondelmonte brothers, and especially that of Giovanni, occurred after the turn of the fourteenth century. Before that time, the population of Florentines that were resident permanently in the Hungarian Kingdom was limited to only a small number of men who served the king as administrators of mines and mints. The Florentine Francesco Bernardi appears first in Hungarian sources in 1373. He started his career during Louis I of Anjou's reign as an officer of royal taxes. He obtained citizenship in Buda, and continued his activity during Sigismund I's reign as an officer of the royal mint. ${ }^{12}$ As Bonaccorso Pitti's diary relates, another Florentine, Bartolomeo di Guido Baldi, provided hospitality for Pitti while he was in Buda in 1375. ${ }^{13}$ Later on, in 1387, Bartolomeo also became an officer of the royal mint. It was probably his son Matteo Baldi who served Pippo Spano in the administration of the salt mines at Vízakna, in Transylvania, and who settled down permanently in Szeben. ${ }^{14}$

Most likely it was also in the 1380s when the adolescent Filippo di Stefano Scolari, better known as Pippo Spano, arrived in Buda with the merchant Luca di Giovanni del Pecchia. ${ }^{15}$ Pippo started his career in the Hungarian Kingdom in a fashion similar to Bonaccorso Pitti and many other merchants: as a shop assistant in training at the Hungarian branch of a Florentine company. The first evidence of Pippo's permanent residency appears in 1393 when the priest of the parish of Santo Stefano at Tizzano reported that Stefano di Francesco's sons had left for the Hungarian Kingdom. ${ }^{16}$ Most likely this occurred while Pippo worked for Archbishop János Kanizsai (c. 1350-1418), who in these years was the main supporter of

tera come l'arciveschovado di Coloccia è dato a messer l'abate di Pecsvaradino di volere di nostro signore messer lo Spano..." ASF Corp. Rel. Sopp 78.326. 277.

${ }_{12}$ Zsuzsa Teke, "Firenzei üzletemberek Magyarországon 1373-1403," Történelmi Szemle 37 (1995): 129-150.

13 "[A]ndai fuori a casa Bartolomeo di Guido Baldi da Firenze, il quale era maestro della moneta di Buda per lo Re," Bonaccorso Pitti, "Ricordi” in ed. Vittore Branca, Mercanti scrittori: Ricordi nella Firenze tra Medioevo e Rinascimento (Milan, 1986), 367.

${ }^{14}$ Elemér Mályusz ed., Zsigmondkori Oklevéltár vol. II/2 (Budapest, 1951-56) 6040; 1613; Vízakna and Szeben today belong to Romania and bear the names: Ocna Sibiului and Sibiu.

${ }^{15}$ Luca del Pecchia was a merchant of the Arte dei Medici e Speziali in the 1380s, ASF Arte dei Medici e Speziali 46. 24v. As a supporter of Naples' ambition for the Hungarian crown, he took an active part in the mediation between Naples and certain Hungarian barons, ASF Signori, Missive I. Cancelleria 21.26v.

16 "Stefano di Francesco è morto già anni iii, non à nulla, i figliuoli se ne sono iti in Ungheria," ASF Estimo 209. 124v. 
Sigismund's politics and who already had personal connections to the city of Florence. Around 1397, Pippo received charge of the archbishop's castle at Simontornya, ${ }^{17}$ where he most likely met the young noblewoman Barbara of Ozora, whom he married around 1399. Pippo was fortunate in that they inherited a modest estate, which carried a noble title. ${ }^{18}$

Around this time Pippo first appeared in King Sigismund's service; he and his brother Matteo were named as administrators of the gold mines at Körmöc, in the northern part of the Kingdom. ${ }^{19}$ Shortly thereafter, in 1403, Pippo defended the king's life against an organized group of barons led by his former master János Kanizsai. ${ }^{20}$ Following this incident, Pippo joined the small inner circle of the royal court, which indicates the king's confidence in him. Pippo also became one of the most important officers in the royal army, campaigning against both Venice and the Hussites. In the early 1400s he obtained his most important offices, the comes camerarum salium regalium (count of the treasuries of the royal salt) and comes Temesiensis (count of Temesvár). On this occasion Pippo received the name Spano, which comes from the italicization of the Hungarian term ispan (comes). ${ }^{21}$ In the capacity of comes Temesiensis, he extended his influence to the southern part of the kingdom by organizing defense systems against the Ottomans, which made him the first Florentine of a military profile in Sigismund's service.

The Florentines were certainly not the only foreigners welcomed to Sigismund's court. Besides a few Hungarian barons, Sigismund's chief

\footnotetext{
${ }^{17}$ For Pippo's early career in Hungary see: Jacopo di Poggio Bracciolini, "Vita di Messer Filippo Scolari” in Archivio Storico Italiano IV (1843): 163-184. Since Iacopo di Poggio did not refer to the exact date of Pippo's nomination and there are no extant archival sources, one might suspect that it was around 1397 when the archbishop received the castle from the king, Pál Engel, Magyarország világi archontológiája, 1301-1457 (Budapest, 1996).

${ }^{18}$ Magyar Országos Levéltár (hereafter: MOL), Diplomatikai Levéltár (hereafter: DL), 87669.

19 Körmöc today belongs to Slovakia and bears the name Kremnica.

${ }^{20}$ Pál Engel, "Ozorai Pipo," in ed. Ferenc Vadas, Ozorai Pipo emlékezete (Szekszárd, 1987), 53-89.

${ }^{21}$ For the congratulations sent by the Signoria on the event, see ASF Signori, Missive I. Cancelleria 25. 11.
} 
advisors and therefore the most important familiares regis were all foreigners after 1403, when the struggle against a rival claimant to the crown, Ladislaus of Naples, ended with Sigismund's victory. Among these advisors were foreigners of modest origins such as the Pole Stibor of Stiboricz, the German Eberhard, or Matko of Talovac, the descendent of a merchant family from Ragusa. ${ }^{22}$ Sigismund bestowed minor responsibilities on Poles, Styrians, Dalmatians and Florentines, all of whom were kinsmen of the abovementioned familiares regis: Stibor, Eberhard and Pippo. Pippo Spano's success was not an isolated incident, but part of Sigismund's greater strategy of building a new loyal elite at the royal court. Moreover, this strategy allowed his familiares to create similar groups of trustworthy men through kinship bonds that shaped their services and assured their loyalty to the crown, which in turn disseminated royal patronage throughout the social hierarchy.

Pippo Spano followed the same strategy as the king in his own affairs, with his brother Matteo (†1426) acting as his chief collaborator in the Hungarian Kingdom. Most likely, the brothers arrived in Buda together and held certain offices cooperatively, for example the administration of gold mines. They were also the co-owners of the castle at Ozora, in the centre of Pippo's estates. ${ }^{23}$ Even though Matteo married into another Florentine magnate family and kept his residence and that of his family in Florence, his activity as a cultural disseminator cannot be ignored. ${ }^{24} \mathrm{His}$ surviving correspondence provides strong evidence that he was acquainted with the Hungarian queen Barbara and other members of the royal court. ${ }^{25}$ As a merchant Matteo imported luxury goods produced by the companies he operated with his Florentine relatives and partners. ${ }^{26}$ Furthermore, Luigi Passerini has argued that Matteo's active participation at his brother's side in the war against the Ottomans in the 1410s might have led Sigismund

\footnotetext{
${ }^{22}$ Ragusa bears the modern name Dubrovnik and today it is located in Croatia.

${ }^{23}$ See the royal permissions for the foundation of the castle, MOL DL 87891; 87893.

${ }^{24}$ For the tax declaration of Pippo Spano's and Matteo's heirs in 1427, see ASF Catasto 59. $870 \mathrm{r}$

${ }^{25}$ As an international merchant, Matteo imported Arabian horses, exotic animals, and other luxury goods to Italy and to the Hungarian Kingdom, ASF Mediceo Avanti il Principato (hereafter MAP) $1.42 ; 68.410 ; 1.44 ; 1.50$.

${ }^{26}$ Matteo founded a company focused on Hungarian business with one of his brotherin-laws, Piero di Bernardo della Rena, Antonio di Geri Bardi, and Tommaso di Domenico Borghini, ASF Corp. Rel. Sopp. 78. 326. 270v.
} 
to bestow a noble title on him. ${ }^{27}$ This partnership is a clear indication of the benefits of sibling cooperation in both politics and markets.

The Scolari brothers' experiences are emblematic of the greater pattern of permanent migration between the Florentine Republic and the Hungarian Kingdom in the late fourteenth and early fifteenth centuries. While several factors influenced Florentine long-term migration to the Hungarian Kingdom, an important pull factor was the information and economic solidarity transmitted by family networks already in place in Hungary. A second factor was the promise of service in the royal administration and the privileges granted by the king to merchants of foreign origin, including the Italian community in Buda. Likewise, a push factor surely was that the Scolari family was magnate and Ghibelline, which disqualified the Scolari from holding offices in Florence. ${ }^{28}$ Had the brothers not migrated to the Hungarian Kingdom, the Scolari might have enjoyed only a modest living in the Florentine countryside. Yet the family's experiences in the Hungarian Kingdom show that they were alert constantly for additional income, most often from mercantile activity or military service. In the 1370s, two Scolari condottieri, Bernardo and Rinieri, fought in the service of the Carrara family against Venice. They were sent also to the Hungarian king as ambassadors and took part in battles against a Hungarian baron, István Laczkfi (†1397) as his allies. ${ }^{29}$ Bernardo and Rinieri were distant uncles to Pippo and Matteo di Stefano Scolari on their father's side. It is unclear how the connections of their agnates affected the Scolari brothers' life in the Hungarian Kingdom. However, there is a revealing connection in Pippo's responsibility for the castle at Simontornya. Prior to 1397, the castle's owner was the same Laczkfi family for whom Pippo's uncles worked. In the 1410s, during the war led by Sigismund against Venice, Pippo cooperated with Francesco Carrara and Brunoro della Scala as his allies, both of whom

${ }^{27}$ Luigi Passerini and Pompeo Litta, "Buondelmonte di Firenze" in Famiglie Celebri di Italia vol. 2. table III. Special Collection, Newberry Library, Chicago.

${ }^{28}$ Francesca Klein, ed., Il libro del chiodo: Riproduzione in fac-simile con edizione ciritica (Florence, 2004), 62; 94; 156. For the Scolari's social status see also, Carol Lansing, The Florentine Magnates: Lineage and Faction in a Medieval Comune (Princeton, 1991).

29 "La guerra da Trevixio nel 1383" in ed. Ludovico Antonio Muratori, Rerum Italicarum Scriptores: Raccolta degli storici italiani dal cinquecento al millecinquecento vol. XVII part 1. vol. III. 238. 
were also sons of his uncles' former employers. ${ }^{30}$ In spite of the scarce information regarding the relationship between the two Scolari branches it is likely that family solidarity prompted Pippo's and Matteo's presence in Buda, just as family connections motivated the migration of other Florentines to the Hungarian Kingdom in the same period.

\section{Florentine Migration to the Hungarian Kingdom Attributed to the Presence of the Scolari Family}

As noted earlier, during the first years of Sigismund's reign there was no change in the migration pattern between the Florentine Republic and the Hungarian Kingdom compared to the previous decades. Yet after the consolidation of Sigismund's reign and Pippo's own power (which depended on the king), there was an increase in the number of long-term migrants from Florence to the Hungarian Kingdom, likely due to the Scolari family's success and their expanding kinship network. The turning point came around 1403, when Pippo aided Sigismund against János Kanizsai's rebellion and afterwards obtained both rank as comes Temesiensis, and influence at the royal court. Unfortunately, there are few sources relevant to the number of people involved in the long-term migration movement between the Florentine Republic and the Hungarian Kingdom. Business and private letters, census records, and other Hungarian and Florentine official records note only broad attention to the Florentine presence in Hungarian territory. Excluding the constantly commuting merchants, Florentines belonging to the migratory group were relatives, neighbors, or close friends of the Scolari. The roles undertaken by Florentines changed slightly with the Scolari presence, since the majority of long-term migrants worked in royal administration, while in a new development a minority of migrants managed civil or ecclesiastical properties.

Generally, the management of ecclesiastical property, either by a lay governor or by a clergyman, was restricted to Hungarian noblemen, and Pippo was the first Florentine to control such estates. Certainly Pippo did not direct his affairs entirely on his own. After Pippo entered the Hungarian nobility he had Hungarian familiares at his disposal. Moreover, beyond

\footnotetext{
${ }^{30}$ Jacopo di Francesco Carrara and Brunoro della Scala became members of the Dragon Order founded by King Sigismund, Elemér Mályusz and Iván Borsa, eds., Zsigmond-kori Oklevéltár I-VII. (Budapest, 1951-2001), 1466; 1507.
} 
his brother Matteo's assistance, his family maintained a network of consorti, a group of kinsmen bound together by law. As a result of Pippo's influence, in the first three decades of the fifteenth century, four Florentines became dignitaries of the Church in the Hungarian Kingdom: Andrea di Filippo Scolari, Giovanni di Andrea Buondelmonte, Carniano Scolari, and Giovanni di Piero Melanesi, all of whom were relatives or close associates of the Scolari. In 1407, Pippo's distant cousin, Andrea Scolari (†1426) became the first Florentine prelate in the Hungarian Kingdom, first as the bishop of Zagreb, and soon after, as the bishop of Várad, which was one of the nearest ecclesiastical properties to Temes county, where Pippo was comes. Andrea kept his residence there from 1409 until his death in 1426. ${ }^{31}$ As noted earlier, another Scolari relative, Giovanni Buondelmonte ( $† 1447)$, served as the Benedictine abbot at Pécsvárad before his election to the archbishopric of Kalocsa. At first Pippo himself managed the episcopal estates of Kalocsa, but from 1420 Carniano Scolari succeeded to the archbishopric and was followed by the aforementioned Giovanni, who occupied the office until $1447 . .^{32}$

In addition to his own estates and the ecclesiastical properties under his influence, Pippo also managed salt and, probably, precious metal mines. In mining administration Pippo received assistance from members of several Florentine families, such as the Del Bene, Bardi, Mannini, and Rinaldeschi families, some of whose members settled permanently in the Hungarian Kingdom. ${ }^{33}$ The most successful among them was undoubtedly Onofrio Bardi and his offspring, who became Pippo's familiares. Following Pippo's own strategy, their success was enhanced and encouraged by marriage with local Hungarian families and, eventually, the receipt of a noble title. ${ }^{34} \mathrm{~A}$ considerable number of Pippo's familiares and supporters were born to merchant families, including Giovanni di Piero Melanesi ( $† 1427)$, who became the bishop of Várad after Andrea Scolari's death in 1426. Most likely Giovanni arrived in the Hungarian Kingdom with his merchant

${ }^{31}$ Pál Engel, Magyarország világi archontológiája 1301-1457 (Budapest, 1996), 77. Today the city of Várad and the county of Temes are part of Romania and bear the names Oradea and Timiş respectively.

32 Ibid., 65-66.

${ }^{33}$ Elemér Mályusz and Iván Borsa, eds., Zsigmond-kori Oklevéltár I-VII (Budapest, 1951-2001).

${ }^{34}$ Onofrio was mentioned as royal factor, ibid., vol. VII. 87; 972. For Onofrio as Pippo's factor, see Rinaldo degli Albizzi, Commissioni di Rinaldo degli Albizzi per il Comune di Firenze dal 1399 al 1433, ed. Cesare Guasti (Florence, 1867-1873), vol. II. 579. 
brothers, Simone, Piero, and Tommaso. The Melanesi were senior partners in one of the few companies established by Florentines in Buda. In the 1420s, the Scolari worked with the Melanesi to export precious metals, especially copper, and to import high quality textiles. In fact, the Melanesi family's success may have depended on Pippo's goodwill as Sigismund's "right hand" in mining administration. ${ }^{35}$ Another company that had a branch in the city of Buda was the Carnesecchi and Fronte, established by Pagolo di Berto Carnesecchi and Antonio di Piero di Fronte in 1415. ${ }^{36}$ Although it is uncertain whether Matteo di Stefano Scolari acted as a partner in this particular company, archival sources reveal several business transactions between the Carnesecchi, Fronte and Scolari brothers. ${ }^{37}$ As these examples show, Pippo and his kin network developed a long-lasting economic cooperation with a considerable number of the Florentine merchants working in the Hungarian Kingdom, to their mutual benefit.

However, the Scolari did not restrict their economic interest to families and companies that arrived in the Kingdom after their success in the early 1400s. Instead, Pippo and Matteo established strong economic links with merchants who migrated in the first part of Sigismund's reign or even before. As noted earlier, the company of Vieri di Cambio de' Medici had developed import-export channels within the Hungarian Kingdom by $1387 . .^{38}$ In the 1390 s they employed Giovanni di Niccolò Tosinghi, a Florentine merchant who had operated in the kingdom in previous years. ${ }^{39}$ After 1400, both Giovanni and his son Scolaio continued to commute between Florence and Buda. ${ }^{40}$ It was probably not coincidental that both the Carnesecchi and Tosinghi families lived in Florence in the Via Panzano, in the close vicinity of the Scolari. ${ }^{41}$ In 1410 when the brothers

\footnotetext{
35 Scolari correspondence provides evidence of close cooperation with the Melanesi brothers in the import-export of precious metals and cloth. ASF Corp. Rel Sopp. 78. 326. 330.

36 ASF Catasto 55. 789r; Catasto 27. 116v; Catasto 476. 811v.

37 ASF Corp. Rel. Sopp. 78. 326. 247r.

38 The company included Guido di messer Tommaso, Andrea di messer Ugone, and Antonio Santi as partners, ASF Signori, Missive I. Cancelleria 21. 11v; 66.

39 ASF Signori, Missive I. Cancelleria 21. 38v; 40r-v.

${ }^{40}$ For the economic cooperation between the Santi and the Scolari see: ASF Monte Comune o delle Graticole (hereafter: Monte) II. 2416. 133v.

${ }^{41}$ In 1405, the Scolari brothers resided at the Via Panzano, ASF Monte II. 1805. 39r. Within a few years, c. 1410, they moved to the Borgo di San Piero Maggiore, which was called at this time Borgo degli Albizzi, ASF Catasto 59. 871r; Catasto 80.599r.
} 
moved to the more prestigious street of Borgo degli Albizzi their new neighbors included their in-law families, the Della Rena, Infangati and Guadagni, all of which had family members working in Hungarian territory after 1400 . Thus it is safe to argue that in the case of the Scolari family, Florentine neighborhood connections were a crucial factor in generating the new migration flow. Information on the possibilities in Buda might have been transmitted not only by family networks but by neighborhood and business networks as well.

Florentine merchants and their kin tended to replicate this cluster pattern seen in Florence while in residence in the Hungarian Kingdom. In the fifteenth century the first evidence of smaller, provincial courts existing in Hungarian territory were connected to the Florentine diaspora. Courts established at Ozora by Pippo, at Várad by Andrea Scolari, and at Kalocsa by Giovanni Buondelmonte became centers of cultural mediation, by providing a meeting point for Florentines who had occasion to travel to the kingdom. All of these provincial courts sat at the heart of their landlords' estates. The smallest court was Pippo's castle at Ozora, which was surrounded by an oppidum, a town of local importance under the landlord's protection, and inhabited mainly by peasant families. The towns of Várad and Kalocsa did not fall into the same category. They were more extensive and varied in terms of geography and population and nevertheless were local centers of the Church. In the 1420s, the episcopal palace at Várad and the archiepiscopal palace at Kalocsa were populated mainly by the Buondelmonte-Scolari relatives and other Florentines. Since there has been no in-depth analysis of these early provincial courts, we can only hypothesize that a greater part of the population of these courts belonged to the Florentine community. At Kalocsa there was a constant presence of Florentine doctors, merchants, and the archbishop's brothers, while Florentine clergymen and other Scolari relatives resided at Várad. ${ }^{42}$ Some of these residents were parenti (relatives in-law) of Matteo Scolari, like Baldinaccio di Catellino Infangati who was the brother of Matteo's wife. The two brothers-in-law ran a workshop together in Florence that specialized

${ }^{42}$ Florentines in Andrea’s court at Várad in 1426 included maestro Giacomo da Sanminato, doctor of medicine, Simone di messer Andrea Buondelmonte, Simone di Piero Melanesi, maestro Alessandro di messer Antonio, doctor of medicine, Giovanni e Pietro di Andrea Lamberteschi e Baldinaccio di Catellino Infangati, ASF Corp. Rel. Sopp.78.326 $.291 \mathrm{r}$. 
in the treatment of wool and probably silk. ${ }^{43}$ High quality goods produced by their workshop might have benefited from the abundant amount of silver and gold imported by the Scolari and by their business partners to Italy. Textiles and goldsmiths' articles might have reached also Várad and other Hungarian markets thanks to the activity of Baldinaccio, who continued to live there even after Andrea Scolari's death in $1426 .{ }^{44}$

Considering that Pippo Spano, and most likely also Andrea Scolari, were substantial patrons of churches and other building projects, and that they faced a shortage of skilled Hungarian craftsmen, it is probable that their courts provided a temporary home for migrant craftsmen. These included well-known Florentine masters such as Manetto di Jacopo Ammanatini, the rotund carpenter about whom a popular story was written, and Maso di Cristofano di Fino, known as Masolino. Thanks to the presence of these craftsmen, the castle of Ozora, built in the heart of Pippo's estate, most likely shared architectural characteristics with the early Renaissance Florentine style. The Florentine-born Tommaso di Cristofano di Fino carried out work for Pippo Spano in Hungary beginning in September 1425 and ending before Masolino returned to Florence sometime after 1427.45 Although there is clear evidence for Masolino's activity in Pippo's service, we can only presume that he worked on the decoration of Pippo's most important building projects, such as his burial chapel at Fehérvár and his main residence at Ozora, which according to Rinaldo degli Albizzi's description boasted richly decorated walls. ${ }^{46}$ Today there are only small fragments of frescoes remaining in the castle's chapel that can be dated to Pippo's residence there.

These building projects offered an opportunity to introduce Florentine aesthetics to their adopted homeland, and the Florentine masters in Scolari's service employ surely imported elements of the early Quattrocento artistic style into the Hungarian Kingdom. The castle at Ozora reveals the combination of elements of medieval Hungarian castle-building and Florentine palace-building. Mere regularity in mass and ground-plan was not entirely new to the structure of Hungarian castles; far more novel was the

\footnotetext{
${ }^{43}$ ASF Corp. Rel. Sopp. 78. 326. 282r.

${ }_{44}$ ASF Catasto 56. 493r. "La persona sua e sostenuta ne paesi d'Ungheria giù fu più tenpo e da llui non posso sapere niente," ASF Catasto 478. 463r.

45 Anthony Molho, "The Brancacci Chapel: Studies in its Iconography and History," in Journal of the Warburg and Courtauld Institutes 40 (1977): 94.

${ }^{46}$ Fehérvár today bears the name: Székesfehérvár.
} 
rectangular cortile surrounded by annexes on each side. Especially extraordinary in Hungarian castles was the lack of any defense system and the use of so-called merlatura alla ghibellina, the swallow-tail shape battlements, used by the Ghibellines in Florence. As the Novella del Grasso Legnainolo, "The Story of the Fat Carpenter," describes, there were Florentine craftsmen working in the Hungarian Kingdom in the early fifteenth century, including Manetto Ammanatini. He arrived at Buda sometime around 1409, before which he was a partner or shop assistant to Filippo di ser Brunellesco, called Brunelleschi. ${ }^{47}$ In the Hungarian Kingdom, both King Sigismund and Pippo employed Manetto, ${ }^{48}$ however, there are no direct sources at our disposal for his collaboration on Pippo's castle at Ozora. Only a letter from Rinaldo di Maso degli Albizzi praising the general splendour of the castle, mentions Manetto, who according to Rinaldo deserved the name Grasso da Ozora. ${ }^{49}$

As these provincial courts illustrate, cooperation between members of the Scolari kinship network also included providing hospitality to relatives and other Florentine citizens travelling in the Hungarian Kingdom. In 1426, the abovementioned Rinaldo di Maso degli Albizzi (1370-1442) arrived as an ambassador of the Florentine Signoria to King Sigismund. After his visit to the royal court, Rinaldo and his fellow ambassador Giuliano di Nello da Sangimignano, accepted an invitation to visit Pippo's residence at Ozora. ${ }^{50}$ Although Pippo addressed the invitation to Rinaldo and Giuliano as representatives of Florence, a stronger motivation for the visit surely was the fact that in the same year the men established a marriage contract between Rinaldo's son Giovanni and Matteo's daughter

${ }^{47}$ Antonio Manetti, Vita di Filippo Bruneleschi preceduta la Novella del Grasso, eds. Domenico de Robertis and Giuliano Tanturli (Milan, 1976) 3-44. "El Grasso e 'l compagno, giunti in Ungheria, si dettono da fare, ed ebbonvi buona ventura; imperò che in pochi anni vi diventarono ricchi, secondo le loro condizioni, per favore del detto Spano, che lo fece maestro ingegneri, e chiamasi maestro Matteo da Firenze," ibid., 42.

48 "[D] i fiorini si pagharono per messer lo Spano Manetto di Jacopo da Firenze per lo lavoro del castel de Sala," ASF Corp.Rel.Sop. 78.326.370v.

49 "[D]etto Grasso da Osora, bene che sia fiorentino," Commissioni di Rinaldo degli Albizzi, 967.

50 "A dì 15, venimo a Osora, luogo principale dello Spano, messer Filippo Scolari Conte di Temescivara... Fumo ricevuto dalla Contessa magnificamente, a sue spese; e feci mostrare il castello bellissimo, e più chiese fatte di nuovo, con molti ricchi paramenti... A dì 16 di maggio 1426, vicitamo la Contessa; e poi come nuovo parente ecc. ci fe festa assai," Commissioni di Rinaldo degli Albizzi, 967. 
Francesca. ${ }^{51}$ This contract bound the two men as relatives, parenti, in addition to revealing how Florentine merchant families reasserted relationships and established social ties with their close neighbors, business partners, and political allies.

As for the other advantages of the Scolari brothers' presence in the kingdom; both the Signoria and Sigismund used them as diplomatic agents. For example, in 1424 Matteo travelled to Florence to pursue his own business needs while acting as the Hungarian ambassador to the Signoria. ${ }^{52}$ Even more glorious for the Scolari was Pippo's arrival as Sigismund's ambassador to Florence in 1410, leading a well-equipped cavalry squad. But Pippo's arrival inspired more fear than happiness for the Florentine government. A long discussion concerning the event remains in the records of the Consulte e Pratiche..$^{53}$ While some Florentine officials argued against welcoming the Hungarian baron with official ceremony, the majority expressed their sympathy for Pippo. It might have had something to do with the fact that politician-merchants like Antonio di Piero di Fronte and Niccolò di Donato Barbadori were business partners of his brother Matteo, while other office-holders, including Matteo di Scelto Tinghi, had long-lasting economic interests in the Hungarian Kingdom. Florentine politicians had several good reasons for considering the situation so carefully, since they were aware of the importance of good relations with the Hungarian crown. Following the conflict between the Hungarian Kingdom and the Kingdom of Naples in 1385/86, the Signoria kept a watchful eye on Hungarian domestic affairs. Information traveled from Buda to Florence via commuting merchants who kept the Signoria up-to-date on all important issues. As a republic of merchants, the Signoria paid special attention to the well-being of their citizens who had business affairs in Buda. Moreover, it is certain that Pippo's mediation at the level of diplomacy had its impact on Florentine-Hungarian economic relations as well.

Using this personal channel provided by Pippo, the Signoria addressed several official letters to him requesting support for the Republic's merchants. Letters of recommendation had been in use for a long time in Florence. Documents of this kind were important in introducing new persons to each other and recommending would-be employees to possible

${ }^{51}$ Rinaldo di Maso degli Albizzi refers to the fact in his tax declaration in 1433, ASF Catasto $479.515 \mathrm{v}$.

${ }^{52}$ ASF Corp. Rel. Sopp. 78. 321. 98r.

53 ASF Consulte e Pratiche 40. 179r. 
employers. Letters were occasionally addressed to the Hungarian royal court as well as to the most influential barons, calling their attention to a new Florentine company or to a single merchant who was engaged in longdistance trade. ${ }^{54}$ Even though in the first decade of Sigismund's reign there were more individuals, like the Count Palatine and the archbishop of Esztergom, who received letters of recommendation, after Sigismund's consolidation of power in 1403, of all the Hungarian barons only Pippo received official letters from the Signoria. ${ }^{55}$ One such letter written in 1405, recommended the already mentioned Fronte di Piero Fronte and his business partners. ${ }^{56} \mathrm{~A}$ year later Fronte's brother Antonio arrived with a letter of recommendation addressed to Pippo Spano from the Signoria. ${ }^{57}$ As far as we know, Fronte had no marriage ties with the Scolari, nor did the two families share ties of neighborhood proximity. While the detailed impact of these letters on the Fronte brothers' careers is uncertain, in the same year of their arrival they appeared to be engaged in business affairs with Matteo Scolari that which lasted for two decades, until Matteo's death in $1426 .{ }^{58}$ To reiterate the close bonds between these men, Pippo himself nominated Antonio to be one of the procurators of Matteo's last will. ${ }^{59}$

In 1427, another letter of recommendation arrived at the royal court on behalf of Antonio, seeking to recoup any economic favor that the Fronte had lost through the deaths of Pippo, Matteo and Andrea Scolari, their business partners and main supporters. ${ }^{60}$ Most likely, this was a substantial loss not only to the Scolari's kinship and business networks, but to the whole Hungarian-Florentine diaspora as well. Thus it is not surprising that many Florentine sources, both chronicles and official documents, commemorated Pippo Spano's death. The authors of the Priorista (1407-1459) recorded the event as follows: "on 27th December at the time of these men

\footnotetext{
${ }^{54}$ One of these letters of recommendation was addressed to Queen Maria of Hungary in 1389, ASF Signori, Missive I. Cancelleria 21. 11v.

55 There were four official letters addressed to Pippo Spano by the Signoria: ASF Signori, Missive I. Cancelleria 25. 3v; 11r; Signori, Missive I. Cancelleria 26. 108v; Signori, Missive I. Cancelleria 27. 14v.

${ }^{56}$ ASF Signori, Missive I. Cancelleria 26. 108v.

57 ASF Signori, Missive I. Cancelleria 27. 14v.

58 As for the partnership between the Fronte and Matteo there are only indirect sources on our disposal, ASF Corp. Rel. Sopp. 78. 326. 279v.

59 ASF Carte Strozziane IV. 635.

${ }^{60}$ ASF Signori Legazioni e Commissarie 7. 80v.
} 
died in Hungary Filippo Scolari, for whom a chapel and a marble sepulcher were made by Emperor Sigismund." ${ }^{61}$

\section{The Florentine Presence in the Hungarian Kingdom after 1426}

So far the evidence presented in this article strongly suggests that brokerage, as exemplified by the activities undertaken by the Scolari brothers, was an important factor in generating a new migration flow. The significance of the Scolari's activities became particularly obvious in the wake of their passing away. During the period after Pippo's and his close relatives' death in 1426, the migration flow declined and conflicts between the Hungarian Kingdom and the Florentine Republic increased; including the arrest by King Sigismund of several Florentines, such as Pippo's old familiares the Lamberteschi brothers. These events all point to the influence of the Scolari brothers as mediators and brokers, whose good relations with the king maintained Florence in royal favor.

There is no doubt that the year 1426 was a turning point for the Hungarian-Florentine diaspora. Matteo and Andrea Scolari died in January 1426 and Pippo followed in December of the same year. There remained in the Hungarian Kingdom only two influential supporters of the Florentine diaspora: Giovanni Melanesi, who became bishop of Várad after Andrea Scolari's death, and Giovanni Buondelmonte, archbishop of Kalocsa. Melanesi did not have the good fortune to enjoy his episcopate for long; he died a few months after his election in 1427. As for Giovanni Buondelmonte's political power, Pippo's influence had ensured his nomination, and so at least in the first years of his career his success depended on the politics of his relative. Assuredly there were certain advantages in the office of archbishop, including prestige, a fair living, the possibility of establishing a small court, and the maintenance of contacts with his homeland through other Florentines. But in the medieval Hungarian Kingdom political power was also the subject of extended properties, a network of

${ }^{61}$ "A dì 27 di dicembre al tempo di questi Signori morì in Ungheria Filippo Scolari al quale da l'Imperatore Sigismondo gli fu fatto una cappella et sepolcro di marmo con questo pitaffio latino et posto nella Propositura di Abba Reale. Sepulcrum egregi viri et magnifici domini Philippi de Scolaribus de Florentia Comitis Themisuariensis et Ozorum qui obiit. A.D. 1426 die 27 dicembris," Pagolo di Matteo Petriboni and Matteo di Borgo Rinaldi, Priorista (1407-1459): With two Appendices (1282-1406) eds. Jacqueline A. Gutwirth and Gabriella Battista (Rome, 2001), 193. 
powerful kin and familiares which were partly missing for Buondelmonte after 1426, who had never obtained Pippo Spano's political and social position, even though according to his rank he was the second most important figure among the Hungarian clergy for two decades.

While there are no statistics detailing the extent of the Florentine community's decline following the Scolari brothers' deaths in 1426, it is significant that from this date onwards no Florentines obtained any influential political positions in Sigismund's Hungarian Kingdom. Several men who succeeded in keeping their offices were the above-mentioned Buondelmonte and Pippo's former factor, Onofrio Bardi and his sons. As noted earlier, Onofrio started his career as an administrator of mines within Pippo's sphere of influence. After that he became familiaris regis, and received a castle and a noble title from Sigismund, thus establishing some political independence from the Scolari. Onofrio's sons and heirs continued their father's profession and served the king in various capacities. Yet, their influence, their offices, and their contribution to royal administration never reached the stature achieved by Pippo.

As universal heirs to Pippo, Matteo, and Andrea, Filippo, Lorenzo, and Giambonino di Rinieri Scolari were not so fortunate. In 1427, only a few months after their uncle's death, they lost control over the salt mines that contributed to the family's wealth. ${ }^{62}$ Various sources show that the three Scolari brothers had managed to maintain the social status and political influence of their uncles without serious repercussions. As an international merchant, Giambonino settled down in Treviso, in the territory of the Venetian Republic in one of the Italian heart of international trade. Meanwhile, Lorenzo and Filippo Scolari continued to follow a back-and-forth pattern between the two lands, cooperating with their fellow- citizens in the import of precious metals to Italy. ${ }^{63}$ They also kept up some of their uncles' connections; for example, periodically they visited Pippo's widow at Ozora. Even though they cultivated good relations with Barbara of Ozora, she could not have entailed her estates-including the castle at Ozora-to the cousins and they did not even obtain a noble title in the kingdom. Therefore, without noble rank and property to draw on they had no chance to enter further into Hungarian political society. Filippo,

${ }^{62}$ Ernő Simonyi, Flórencz Okmánytár vol. II., Magyar Tudományos Akadémia Kézirattára, Budapest 135 .

${ }^{63}$ See the Scolari brothers' correspondence from 1429, ASF Corp. Rel. Sopp. 78. busta 326. 
Lorenzo, and Giambonino remained at the level of an ordinary Florentine merchant who had no roots or political power in the Hungarian Kingdom. Using the few connections they had, the cousins were occupied with attempts to collect money from their uncles' debtors who were quite unwilling to pay. ${ }^{64}$

Even before 1426 similar commercial tension had occasionally occurred between Florentine merchants and Hungarian noblemen, as well as between members of the Florentine community. Beneath the prosperous surface, the Florentine community was not nearly as peaceful as it appeared at first glance. Following Pippo's death the intermittent financial tensions were exacerbated by the king's increasing disfavor towards the Florentine community. The experiences of the Lamberteschi family reveal how Pippo's personal relationship with the king provided protection for the prosperous merchant community. In the Hungarian Kingdom, the Lamberteschi profited from companies run by Bernardo di Lamberto (c. 1366-c. 1433) and his distant agnate, Andrea di Tommaso Lamberteschi's (c. 1356-c. 1433) sons. The earliest extant records of Andrea's Florentine company show that in 1401 he participated in the wool business in various European cities, including Venice and Buda. Andrea had five sons, all of whom became international merchants. Tommaso di Andrea (c.1377-c.1433) worked as an agent in his father's company and travelled through Europe for business purposes. ${ }^{65}$ Meanwhile, Andrea's two other sons, Niccolò and Giovanni, had already left their father's company in 1427 to work on their own. ${ }^{66}$ Four of the brothers lived and worked in the Hungarian Kingdom. Giovanni and Piero lived in Andrea Scolari's court at Várad, where they shared economic interests with the bishop. ${ }^{67}$ Two other brothers, Niccolò and Vieri, became Pippo Spano's familiares.

The death of Pippo Spano had probably an additional impact on the Lamberteschi brothers. As letters addressed to the Scolari bishop indicate, the Lamberteschi brothers had never been trustworthy towards their clients. They were known to be debtors and apparently it was quite impossible to force them to pay ${ }^{68}$ Even though Florentine merchants complained

\footnotetext{
${ }^{64}$ The Scolari brothers had an argument with the count of Modrusa, Niccolò Frangipane, ASF Corp. Rel. Sopp. 78. 321. 98r-99v.

${ }^{65}$ ASF Corp. Rel. Sopp. 78. 326. 334.

${ }^{66}$ ASF Catasto 27. 92v.

${ }^{67}$ ASF Corp. Rel. Sopp. 78. 326. 291r.

${ }^{68}$ A Florentine merchant, Niccolò di Giovanni Falcucci was complaining to Andrea Scolari about the Lamberteschi's huge debt, ASF Corp. Rel. Sopp. 78. 326. 328.
} 
about the Lamberteschi's behavior, which might have reached Sigismund's own ears, the brothers surely felt protected by Pippo Spano's presence as an ad hoc leader of the expatriate Florentine community. Yet, in 1427, there was nobody to defend them against the king's and other merchants' discontent. Even Giovanni Buondelmonte was helpless to prevent Niccolò and Giovanni's imprisonment by royal commission. In his letters addressed to the Signoria, the Florentine ambassador Piero di Luigi Guicciardini described the Florentines' situation as very unfortunate. Not only did the Lamberteschi experience difficulties, but their agent Gianozzo di Vanni Cavalcanti and Gaspare da Colle, the administrator of mines, also followed them to prison. ${ }^{69}$ In the year 1427 alone the king imprisoned at least six Florentine merchants and confiscated substantial amounts of cash.

These imprisonments and confiscations were clear signs that Sigismund did not trust the Florentine community as much as he did before 1426 while Pippo Spano lived. However, as a Scolari letter indicates, the king had a reputation for acquisitiveness and might have envied the riches acquired by Florentine merchants through the period of good economic relations. Yet, there were Florentine families, Pippo's old familiares working in the administration sector, who were able to keep their offices: members of the Mannini, Del Bene, Bardi, and Zati families, as well as Rinaldo di Dego Rinaldeschi and Gasparre da Colle, returned to his post after his imprisonment. While there were many Florentines who maintained their posts in Hungarian royal administration, ${ }^{70}$ the more general downturn of Florentine affairs in the Hungarian Kingdom signals the importance of personal relations within business circles. Moreover, these experiences clearly highlight that in an evaluation of the Florentine diaspora the merchant population is less important than an analysis of Pippo Spano's impact on the relationship between the Hungarian Kingdom and the Florentine Republic. Most importantly, there was no Florentine either before or after Pippo's time who occupied such an influential position in Hungarian politics. As this article has shown, Pippo's substantial power and influence was

69 "I fiorentini ci sono mal veduti e per pichola chosa, inchamerati e confiscati i loro beni," Simonyi, Flórencz Okmánytár vol. II, 94-95, 110; Letters of ambassador Luigi Guicciardini addressed to the Signoria in 1427, ASF Signori, Legazioni e Commissarie 7. 76v-90r.

${ }^{70}$ For the administration of salt mines in Transylvania see, Draskóczy István, "Só a középkori Magyarországon," in Gazdaság és gazdálkodás a középkori Magyarországon: gazdaságtörténet, anyagi kultúra, régészet (Budapest, 2008), 147-162. 
based not only on his position as a baron, soldier, and merchant, but also on the extensive networks of his kin and familiares.

\section{Conclusion}

The special status attained by Florentines in Hungarian politics and the economy in the first three decades of the fifteenth century in Sigismund's reign can largely be attributed to the influence of Pippo Spano. As a cultural mediator, his presence helped facilitate relations between his native Florence and his adopted country, and his activities promoted reciprocal knowledge and comprehension aimed at maintaining a positive relationship between the two political entities.

In the early fifteenth century, the true migration flow and the phenomenon of intense commuting were generated mainly by two groups both of which had connections with the Scolari family. The first group included Florentines arriving in the Hungarian Kingdom who were relatives, neighbors or friends to the Scolari (i.e., the Buondelmonte family). The second group included experienced merchants already present at Hungarian markets who found stability as business partners or familiares of Pippo's family (i.e., Giovanni Tosinghi). Since the Hungarian Kingdom was strongly centralized in terms of politics and economy, international merchants who obtained significant financial or social advantage were privileged with representation at the royal court. Pippo Spano was not only a voice to Florentines as many other merchants or ambassadors of the city-state, but the benefactor and protector of his fellow-citizens in political and economic debates as the most influential Florentine ever in Hungarian politics. 
